as president. In his address, General Wimberley pointed out that university training is a privilege not to be lightly wasted, and discussed the importance of selecting entrants to universities both on their academic standards and on their potentialities as responsible citizens with the character and inclination to take a leading part in their chosen careers. Three lectures were given at the meeting by, respectively, Prof. G. D. Preston, Harris professor of physics ; Prof. D. H. Everett, professor of chemistry ; and Prof. D. R. Dow, professor of anatomy. Prof. Preston spoke of the work in progress in the Department of Physics, much of which is concerned with the fine structure of matter, and an account was given of the many techniques being used, including electron microscopy and also X-ray diffraction by organic crystals, protein monolayers, bone structures and organic fibres such as jute. Prof. Everett discussed the teaching of quantum mechanics and modern valency theory, and outlined an approach which has been used in presenting the basic principles to first-year students using pictorial examples and mechanical models, all of which can be constructed in a school workshop. Speaking on The Human Brain", Prof. Dow described various electronic methods of investigation and some of the striking results of the new knowledge obtained in these investigations carried out by Prof. W. Penfield, of Montreal, and others. In particular, he discussed recent work on the frontal lobes of the brain and the operation of leucotomy. During the period of the meeting visits were arranged to representative industrial undertakings in Dundee and the surrounding district, to the Pitlochry hydroelectric scheme and to St. Andrews University Observatory to see the new Schmidt telescope. One afternoon was set aside for conducted tours of the Botany, Zoology, Chemistry, Biochemistry and Physics Departments of University College, Dundee.

\section{Metallurgical Conference in Reutte, Tyrol}

Dr. PaUl Schwarzkopf, president of the American Electro Metal Corporation, New York, and owner of the Metallwerk Plansee, Reutte, Tyrol, is organizing an international seminar on metallurgy, entitled "De re metallica", to be held in Reutte during June 22-26. The meeting will be divided into three sessions on physical metallurgy, hard metals and general powder metallurgy, respectively. A number of lectures will be given by scientific workers from Austria, Germany, Switzerland, France, Great Britain and the United States. Further details can be obtained from Dr. R. Kieffer, Metallwerk Plansee, Reutte/Tyrol, or from Dr. W. Leszynski, Powder Metallurgy Bulletin, 320 Yonkers Avenue, Yonkers 2, New York, or from Mr. M. Littmann, Metro-Cutanit, Ltd., 160 Piccadilly, I condon, W.1.

\section{Overseas Scholarships of the Royal Commission for the Exhibition of 1851}

The Royal Commissioners for the Exhibition of 1851 have awarded the following overseas scholarships for 1952 , of value $£ 450-500$ a year and tenable for two years, for research to be undertaken in the institutions as shown. Canada: I. B. MeDiarmid (Queen's University, Kingston, Ontario), nuclear physics at the University of Manchester; and R. S. Title (University of Toronto), physics at the University of Oxford. Australia: T. M. Dunn (University of Sydney), physical chemistry at University College,
London, or the University of Cambridge ; H. Hoffman (University of Melbourne), nerve physiology at the National Institute for Medical Research, London; and R. Pettit (University of Adelaide), organic chemistry at University College, London. New Zealand: R. B. Johns (University of New Zealand), organic chemistry at the University of Cambridge. South Africa: S. Brenner (University of the Witwatersrand), physiological chemistry at the University of Oxford ; and A. R. H. Martin (Rhodes University, Grahamstown), botany at the University of Cambridge or University College, Ivondon. Republic of Ireland: D. H. Hayes (Trinity College, Dublin), organic chemistry at the University of Cambridge. India: H. K. Jain (Indian Agricultural Research Institute, New Delhi), plant breeding at the University College of Wales, Aberystwyth.

\section{Announcements}

THE following appointments in the National Agricultural Advisory Service have been announced : A. Jones, to be chief farm-management advisory officer, in which post he will be responsible for developing and co-ordinating farm-management advisory work throughout Great Britain; and J. W. Reid, county agricultural officer for the County of Shropshire, to be deputy provincial director for the South-Western Provincial Sub-centre, Starcross, Devon.

THE Challenger Society is offering small grants in aid of research in marine biology or oceanography at a recognized laboratory during the year June 1952June 1953. Applications, accompanied by details of the proposed research, should reach the honorary secretary, Mr. N. B. Marshall, British Museum (Natural History), London, S.W.7, before the end of May.

THE managers of the Eroodbank Fund, which is for the furtherance of research in biochemistry or biophysics with special reference to the principles and practice of food preservation, are offering a research fellowship of value $£ 600-1,000$ a year (plus research expenses), tenable at the University of Cambridge for a maximum of three years. The closing date for applications is May 31. Further details can be obtained from the University Registry, Old Schools, Cambridge.

IN memory of John Stewart Dow, the Illuminating Engineering Society is offering a prize, derived from a bequest by him, which it is hoped will encourage collaboration between students of illuminating engineering and students in other fields in which applied lighting plays an important part. The prize is of total value $£ 75$ and is intended primarily for students working in collaboration as a team. The subject this year is the layout, artificial lighting and decoration of a ground-floor showroom. Competitors must have been born on or after April 1, 1926. The closing date is November 30. Further details can be obtained from the secretary of the Illuminating Engineering Society, 32 Victoria Street, London, S.W.1.

Erratum. In the article on the Pacific Science Association in Nature of April 19, p. 659, it is stated that the United Nations Educational, Scientific and Cultural Organization contributed 20 million dollars to enable scientific workers from war-devastated countries to attend the Association's seventh congress (1949); this is incorrect, the grant made being 20 thousand dollars. 